Bangladesh J. Bot. 44(2): 177-183, 2015 (June)

\title{
EFFECTS OF DROUGHT STRESS ON GROWTH PARAMETERS, ENZYME ACTIVITIES AND PROLINE CONTENT IN CHICKPEA GENOTYPES
} EMine GöKMEN AND ERCAN CEYHAN ${ }^{*}$

Department of Field Crops, Agricultural Faculty, Selcuk University, 42075 Konya, Turkey

Key words: Chickpea, Drought, Growth, Enzyme, Proline

\begin{abstract}
Drought stress decreased leaf water absorption capacity and real water content and increase relative water content in genotypes of chickpea. It decreased chlorophyll a and b content. Drought increased peroxidase superoxide dismutase, glutathione reductase, ascorbate peroxidase and catalase in stress groups. Proline content increased drastically index stress condition.
\end{abstract}

\section{Introduction}

Chickpea is the third pulse crop followed by bean and pea in world production. It is clear that the sowing area, production and yield of chickpea decreased during the last ten years (Ceyhan et al. 2007, Ceyhan et al. 2012a). The main cause of reducing of yield is biotic (Ascochyta rabiei) and abiotic (high temperature and drought) factors. A closed basin Central Anatolian region is one of the most affected regions by drought (Ceyhan et al. 2012a). This region has almost $50 \%$ of the total chickpea production in Turkey. Drought considerably affect chickpea cultivation, drought tolerant line of chickpea is none (Singh 1997). Drought is known as the most important abiotic stress factor over the world (Ceyhan et al. 2012a) and it causes loss in yield of the cold climate pulses (Singh 1997). Drought stress in plants induces physiological, biochemical and molecular changes for adaptation (Arora et al. 2002, Kalefetoğlu 2006).

Number of work related to drought stress in chickpea is very few. Effect of drought on physiological and biochemical changes chickpea genotypes is reported.

\section{Materials and Methods}

A total of ten genotypes were collected from six local population (Kadinhani LP, Altinekin LP, Hadim LP, Cumra LP, KarapinarLP and Beysehir LP) from city of Konya, two standard cultivar (Canitez and Kusmen-99) and two genotypes (22117 and 22223) from ICARDA (drought tolerant). The pots which had a volume of 1 liter $(14 \times 13 \mathrm{~cm})$ were washed and sterilized for planting in greenhouse. The seeds of genotypes were exposed to $5 \%$ sodium hypochlorite for 3 min and then washed for 3 times with de-ionized water for sterilization. Subsequently, seeds were sown in uncontaminated pots.

The experiment was conducted in "Randomized Plots Factorial Design with Two Factors" with three replications in a fully controlled research greenhouse in Department of Soil Sciences and Plant Nutrition, Faculty of Agriculture, University of Selcuk in 2009. Sowing was made by hand on 15th of February 2009.

The top sides of pots were closed for one week after sowing and placed in the greenhouse at $25^{\circ} \mathrm{C}$ temperature and $40-50 \%$ relative humidity. The top sides of pots were opened after seeds were germinated. The seedlings were grown in the greenhouse under $25^{\circ} \mathrm{C}$ and $40-50 \%$ relative

*Author for correspondence: <eceyhan@selcuk.edu.tr>. 
humidity conditions for 40 days after emergence. Then, the plants were classified as control (0 Day), and three stress groups (3rd, 5th and 7th day) (Ceyhan et al. 2012 b). Drought stress was applied by non-irrigation for 3, 5 and 7 days. The harvest was made in the same order with stress groups which was started with 0 day (40 days after emergence), and following $3 \mathrm{rd}$, 5th and 7 th days of stress (Ceyhan et al. 2012 b).

Some physiological and biochemical analysis were made on the leaf tissue of harvested stress and control groups in trial. Leaf water absorption capacity (LWAC), relative water content (RWC) and real water content (REWC) were determined according to the method of Clarke and McGaig (1982) and Farrant (2000). The amount (mg/l) of chlorophyll a, chlorophyll b and total chlorophyll $(\mathrm{a}+\mathrm{b})$ were determined according to Lichtenthaler (1987).

Leaf samples $(0.5 \mathrm{~g})$ were frozen (separately) in liquid nitrogen and stored in deep freezer $\left(80^{\circ} \mathrm{C}\right)$. Likewise, $0.1 \mathrm{~g}$ leaf samples were also frozen in liquid nitrogen and stored in deep freezer $\left(80^{\circ} \mathrm{C}\right) .0 .5 \mathrm{~g}$ leaf samples were homogenized in liquid nitrogen with $\% 2 \mathrm{w} / \mathrm{v}$ polyvinylpolyprrolidone (PVPP) and $1 \mathrm{mM}$ EDTA, $\mathrm{pH} \mathrm{7,8}$ and $50 \mathrm{mM}$ Na-phosphate buffer medium. After filtration, centrifuge was made on $+4^{\circ} \mathrm{C}, 14000 \mathrm{rpm}$ for $30 \mathrm{~min}$. These processes were made separately for each of the peroxidase (POD), superoxide dismutase (SOD), glutathione reductase (GR), ascorbate peroxidase (APX), catalase (CAT) and proline analysis (Kumar and Kahn 1982, Beauchamp and Fridovich 1971, Bates et al.1973, Foyer and Halliwell 1976, Nakano and Asada 1981, Bergmeyer 1970).

\section{Results and Discussion}

LWAC of stress groups showed that the genotypes Karapinar LP (0.0063 g/gh), Kusmen 99 $(0.0060 \mathrm{~g} / \mathrm{gh})$ and $22223(0.0054 \mathrm{~g} / \mathrm{gh})$ had more LWAC. Means of genotypes showed that the highest LWAC belongs to control group $(0.0132 \mathrm{~g} / \mathrm{gh})$. As increasing in drought stress; LWAC decreased (Table 1). An important level of reduction in the LWAC of the genotypes occurred by application of drought stress compared with their own controls. The same result was also reported by Ceyhan et al. (2012b).

RWC of stress groups showed that the highest value was observed in the genotype Canitez $(81.89 \%)$ while the lowest value was observed in genotype Beysehir LP (66.40\%) (Table 2). The RWC values decreased compared to their control genotypes Kadinhani LP, Altinekin LP, Hadim LP, Karapinar LP and Beysehir LP but that decreased in the other genotypes (Table 2). Many researchers implicated that drought had negative effect on RWC in the plants (Anyia and Herzog, 2004, Ceyhan et al. 2012b). RWC decreased in bean even after closing of stoma (Costa Franca et al. 2000) and in chickpea (Kalefetoğlu 2006) following stress application. On the other hand, Turkan et al. (2005) described the high RWC in the drought-resistant Phaseolus acutifolius was due to high content of proline.

REWC of stress groups showed that the highest value was observed on the genotype Kusmen 99 (83.41\%). Means of the genotypes showed that the highest REWC value $(84.47 \%)$ was found on control group (Table 1). The REWC values decreased comparing with their control of the genotypes Kadinhani LP, Altinekin LP, Hadim LP, Karapinar LP and Beysehir LP while an increasing was observed in the other genotypes (Table 2). Kalefetoğlu (2006) working with chickpea observed reducing in REWC compared to controls by increasing the drought.

Effect of drought on chlorophyll content: Chlorophyll a of the stress groups ranged from 1.62 (Kadinhani LP) to $3.78 \mathrm{mg} / 1$ (Kusmen 99). Means of the genotypes showed the highest value $(2.640 \mathrm{mg} / \mathrm{l})$ in control group while the lowest value $(2.08 \mathrm{mg} / \mathrm{l})$ was observed on 7 days stress group (Table 1). All the genotypes showed an important decrease for chlorophyll a content as from 3 days compared with their own control group (Table 1). 
Chlorophyll $\mathrm{b}$ of the stress groups produced the highest value Canitez and it was followed by Kadinhani and Altinekin $(2.518,1.960$ and $1.935 \mathrm{mg} / \mathrm{l}$, respectively). The lowest value occurred on Karapinar LP with $0.842 \mathrm{mg} / \mathrm{l}$ of chlorophyll b content (Table1).

Table 1. Effects of drought on LWAC, RWC, REWC and chlorophyll a, b, a+b inchickpea genotypes.

\begin{tabular}{lllllll}
\hline & LWAC & RWC & REWC & Chlorophyll a & Chlorophyll b & $\begin{array}{l}\text { Chlorophyll } \\
\mathrm{a}+\mathrm{b}\end{array}$ \\
\hline & $\mathrm{g} / \mathrm{gh}$ & $\%$ & $\%$ & $\mathrm{mg} / \mathrm{l}$ & $\mathrm{mg} / 1$ & $\mathrm{mg} / 1$ \\
Stress groups & & & & & & \\
Control & $0.0132 \mathrm{a}^{*}$ & 73.92 & $84.47 \mathrm{a}$ & $2.640 \mathrm{a}$ & $1.613 \mathrm{a}$ & $4.243 \mathrm{a}$ \\
3rd day & $0.0021 \mathrm{~b}$ & 76.31 & $80.69 \mathrm{~b}$ & $2.520 \mathrm{~b}$ & $1.464 \mathrm{~b}$ & $3.975 \mathrm{~b}$ \\
5th " & $0.0018 \mathrm{~b}$ & 78.18 & $80.69 \mathrm{~b}$ & $2.380 \mathrm{c}$ & $1.301 \mathrm{~d}$ & $3.681 \mathrm{c}$ \\
7th " & $0.0018 \mathrm{~b}$ & 76.31 & $76.30 \mathrm{c}$ & $2.076 \mathrm{~d}$ & $1.386 \mathrm{c}$ & $3.463 \mathrm{~d}$ \\
\hline Genotypes & & & & & & \\
Kadinhani & $0.0040 \mathrm{efg}$ & $68.25 \mathrm{~cd}$ & $79.75 \mathrm{~cd}$ & $1.617 \mathrm{~h}$ & $1.960 \mathrm{~b}$ & $3.577 \mathrm{f}$ \\
Altinekin & $0.0046 \mathrm{de}$ & $72.69 \mathrm{bcd}$ & $79.34 \mathrm{~d}$ & $1.775 \mathrm{~g}$ & $1.935 \mathrm{~b}$ & $3.714 \mathrm{e}$ \\
Hadim & $0.0045 \mathrm{def}$ & $76.50 \mathrm{ab}$ & $80.33 \mathrm{~cd}$ & $2.100 \mathrm{f}$ & $0.925 \mathrm{de}$ & $3.023 \mathrm{i}$ \\
Cumra & $0.0048 \mathrm{~cd}$ & $81.85 \mathrm{a}$ & $80.30 \mathrm{~cd}$ & $3.258 \mathrm{~b}$ & $1.009 \mathrm{~d}$ & $4.259 \mathrm{~b}$ \\
Canitez & $0.0038 \mathrm{fg}$ & $81.89 \mathrm{a}$ & $80.84 \mathrm{bcd}$ & $1.483 \mathrm{i}$ & $2.518 \mathrm{a}$ & $3.989 \mathrm{~d}$ \\
Kusmen & $0.0060 \mathrm{ab}$ & $80.43 \mathrm{ab}$ & $83.41 \mathrm{a}$ & $3.783 \mathrm{a}$ & $1.376 \mathrm{c}$ & $5.159 \mathrm{a}$ \\
22117 & $0.0042 \mathrm{~d}-\mathrm{g}$ & $81.30 \mathrm{a}$ & $83.07 \mathrm{ab}$ & $2.975 \mathrm{c}$ & $1.039 \mathrm{~d}$ & $4.013 \mathrm{~cd}$ \\
Karapinar & $0.0063 \mathrm{a}$ & $75.55 \mathrm{abc}$ & $79.56 \mathrm{~cd}$ & $2.508 \mathrm{e}$ & $0.842 \mathrm{e}$ & $3.346 \mathrm{~g}$ \\
2223 & $0.0054 \mathrm{bc}$ & $76.95 \mathrm{ab}$ & $81.78 \mathrm{abc}$ & $1.733 \mathrm{~g}$ & $1.448 \mathrm{c}$ & $3.183 \mathrm{~h}$ \\
Beysehir & $0.0036 \mathrm{~g}$ & $66.40 \mathrm{~d}$ & $77.02 \mathrm{e}$ & $2.808 \mathrm{~d}$ & $1.356 \mathrm{c}$ & $4.143 \mathrm{bc}$ \\
\hline
\end{tabular}

Chlorophyll $(\mathrm{a}+\mathrm{b})$ content of the stress groups showed that the highest values were as followed: 5.159, 4.259 and $4.143 \mathrm{mg} / \mathrm{l}$ on the genotypes Kusmen 99, Cumra LP and Beysehir LP respectively. The lowest value was $3.023 \mathrm{mg} / \mathrm{l}$ which occurred on the genotype Hadim LP (Table 1). Many researchers found that the plants under drought stress decreased content of chlorophyll a, b, (a+b) content (Costa Franca et al. 2000, Fu and Huang 2001, Kalefetoğlu 2006, Ceyhan et al. 2012b).

Effect of drought on peroxidase, superoxide dismutase and glutathione reductase content: POD content of the genotypes of stress groups ranged from 98.88 (control) to $228.38 \mathrm{nmol} \mathrm{H}_{2} \mathrm{O}_{2}$ $\mathrm{min} / \mathrm{mg} /$ protein (7 day stress). The highest value of the POD was $194.16 \mathrm{nmol} \mathrm{H}_{2} \mathrm{O}_{2}$. $\mathrm{min} / \mathrm{mg} /$ protein on the genotype Kusmen 99 . POD values of the genotypes increased by increasing of stress (Table 2).

Many of the previous researchers reported POD is affected by drought stress (Turkan et al. 2005, Kalefetoğlu 2006, Ceyhan et al. 2012b). Kalefetoğlu (2006) implicated that POD activity increases depending on increasing of drought stress in chickpea and, the cell membranes might be protected by high level of POD activity. Similarly, Turkan et al. (2005) found that POD content was higher in drought resistant bean genotype.

SOD content of the genotypes showed the highest value on 7 days of stress group (1351.00 unit $\mathrm{mg} /$ protein) while the lowest value was taken from the control group (373.53 unit $\mathrm{mg} /$ protein). The highest value was 1155.72 unit mg/protein on the genotype Kadinhani LP (Table 2). Kalefetoğlu (2006) stated that total SOD activity varied between the genotypes and lines under 
various intensity of drought stress. Shao et al. (2005) reported that wheat genotypes under water scarcity in the soil should had different levels of SOD content. The reduction in SOD content of the genotypes Kadinhani, 22117 and Canitez implicated that drought was the limiting factor for SOD activity (Fu and Huang 2001, Jiang and Ren 2004, Kalefetoğlu 2006, Ceyhan et al. 2012b).

GR stress groups showed the highest GR contents ranged from 67.26 (Kadinhani LP) to $100.45 \mathrm{n}$ mol NADPH min/mg/protein (Cumra LP). According to the means of the genotypes, the highest GR value was $101.90 \mathrm{n}$ mol NADPH $\mathrm{min} / \mathrm{mg} /$ protein in 7 days of stress group while the lowest GR value was $64.50 \mathrm{n}$ mol NADPH. $\mathrm{min} / \mathrm{mg} /$ protein in the control group. The stress groups of 3 days and 5 days were in between the values of 83.51 and $96.09 \mathrm{n} \mathrm{mol} \mathrm{NADPHmin}{ }^{-1}$ $\mathrm{mg}$ /protein, respectively (Table 2).

Table 2. Effects of drought on POD, SOD, GR, APX, CAT and proline in chickpea genotypes.

\begin{tabular}{|c|c|c|c|c|c|c|}
\hline & POD & SOD & GR & APX & CAT & Proline \\
\hline & $\begin{array}{c}\mathrm{nmol} \\
\mathrm{H}_{2} \mathrm{O}_{2} / \mathrm{min} / \\
\mathrm{mg} / \text { protein }\end{array}$ & $\begin{array}{l}\text { unit/mg/ } \\
\text { protein }\end{array}$ & $\begin{array}{c}\text { nmol } \\
\begin{array}{c}\text { NADPH.min } / \mathrm{mg} / \\
\text { protein }\end{array}\end{array}$ & 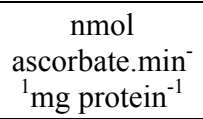 & $\begin{array}{c}\mathrm{nmol} \\
\mathrm{H}_{2} \mathrm{O}_{2} \cdot \min / \\
\mathrm{mg} / \text { protein }\end{array}$ & $\mu \mathrm{g} / \mathrm{TA}$ \\
\hline \multicolumn{7}{|c|}{ Stress groups } \\
\hline Control & $98.88 \mathrm{~d}$ & $373.53 \mathrm{~b}$ & $64.50 \mathrm{~d}$ & $78.02 \mathrm{~d}$ & $60.71 \mathrm{c}$ & $1.68 \mathrm{~d}$ \\
\hline 3rd day & $137.94 \mathrm{c}$ & $1223.63 \mathrm{a}$ & $83.51 \mathrm{c}$ & $111.08 \mathrm{c}$ & $69.59 \mathrm{~b}$ & $10.82 \mathrm{c}$ \\
\hline 5th day & $176.69 \mathrm{~b}$ & $1317.14 \mathrm{a}$ & $96.09 \mathrm{~b}$ & $145.99 \mathrm{~b}$ & $76.57 \mathrm{a}$ & $12.25 \mathrm{~b}$ \\
\hline 7th day & $228.38 \mathrm{a}$ & $1351.00 \mathrm{a}$ & $101.90 \mathrm{a}$ & $182.46 \mathrm{a}$ & $77.01 \mathrm{a}$ & $15.26 \mathrm{a}$ \\
\hline \multicolumn{7}{|l|}{ Genotypes } \\
\hline Kadinhani & $128.39 \mathrm{f}$ & 1155.72 & $67.26 \mathrm{f}$ & $101.90 \mathrm{~d}$ & $69.02 \mathrm{~cd}$ & $8.80 \mathrm{ef}$ \\
\hline Altinekin & $192.27 \mathrm{a}$ & 1154.88 & $85.11 \mathrm{~cd}$ & $132.79 \mathrm{~b}$ & $67.19 \mathrm{~d}$ & $9.66 \mathrm{de}$ \\
\hline Hadim & $149.05 \mathrm{~d}$ & 822.51 & 94.42 b & $130.45 \mathrm{~b}$ & $70.32 \mathrm{c}$ & $9.80 \mathrm{~cd}$ \\
\hline Cumra & $132.01 \mathrm{f}$ & 1053.07 & $100.45 \mathrm{a}$ & $133.77 \mathrm{~b}$ & $80.01 \mathrm{a}$ & $8.44 \mathrm{f}$ \\
\hline Canitez & $167.73 \mathrm{~b}$ & 849.80 & $81.89 \mathrm{e}$ & $132.17 \mathrm{~b}$ & $66.72 \mathrm{de}$ & $12.27 \mathrm{a}$ \\
\hline Kusmen & $194.16 \mathrm{a}$ & 956.89 & $79.32 \mathrm{e}$ & $125.54 \mathrm{c}$ & 79.69 a & $10.85 \mathrm{~b}$ \\
\hline 22117 & $159.80 \mathrm{c}$ & 1014.21 & $82.13 \mathrm{de}$ & $126.39 \mathrm{c}$ & $68.77 \mathrm{~cd}$ & $12.59 \mathrm{a}$ \\
\hline Karapinar & $140.84 \mathrm{e}$ & 965.11 & $87.36 \mathrm{c}$ & $126.15 \mathrm{c}$ & $69.70 \mathrm{c}$ & $8.60 \mathrm{f}$ \\
\hline 22223 & $190.95 \mathrm{a}$ & 1053.38 & $94.70 \mathrm{~b}$ & $153.35 \mathrm{a}$ & $73.57 \mathrm{~b}$ & $10.70 \mathrm{bc}$ \\
\hline Beysehir & $149.53 \mathrm{~d}$ & 989.08 & $92.36 \mathrm{~b}$ & $131.38 \mathrm{~b}$ & $64.70 \mathrm{e}$ & $8.30 \mathrm{f}$ \\
\hline
\end{tabular}

*Figures in the same line column a common letter are not significantly different.

The chickpea genotypes Canitez and AkN 209 showed an increasing in the GR content on the stress level of seven days (Kalefetoğlu 2006). The leaves of chickpea (Kalefetoğlu 2006, Ceyhan et al. 2012b) and bean plants (Turkan et al. 2005) exposed drought increased the content of GR. Moran et al. (1994) reported that content of GR decreased in pea following drought stress while Keles and Öncel (2002) observed an increase in wheat.

Ascorbate peroxidase content: Drought stress groups showed the lowest APX activity in the genotype Kadinhani LP (101.90 nmol ascorbate/min mg/protein) while the highest value was in the genotype 22223 (153.35 nmol ascorbate/min mg/protein) (Table 2). Means of the genotypes showed the highest APX content as a value of $182.46 \mathrm{nmol}$ ascorbate $/ \mathrm{min} \mathrm{mg} /$ protein from 7 days stress application while the lowest value was $78.02 \mathrm{nmol}$ ascorbate/min $\mathrm{mg} /$ protein in the control group. The stress groups of 3 and 5 days ranged from 111.08 to $145.99 \mathrm{nmol}$ ascorbate/min 
$\mathrm{mg} /$ protein, respectively (Table 2). Turkan et al. (2005) implicated that, in the drought resistant bean (Phaseolus acutifolius L.), content of APX plays an important role in combating drought stress. Kalefetoğlu (2006) and Ceyhan et al. (2012b) revealed that content of APX increased depending on drought in chickpea.

Catalase content: Means of the stress groups showed the highest value as $80.01 \mathrm{nmol}$ $\mathrm{H}_{2} \mathrm{O}_{2}$ min $\mathrm{mg} /$ protein in the genotype of Cumra LP while the lowest value obtained as $64.70 \mathrm{nmol}$ $\mathrm{H}_{2} \mathrm{O}_{2}$ min $\mathrm{mg} /$ proteinin the genotye Beysehir LP and, the rest of the genotypes were ranged between these values. Activity of CAT in all the genotypes increase following 3 days of drought stress (Table 2). Turkan et al. (2005) reported that content of CAT acts significantly in the drought resistant bean (Phaseolus acutifolius L.). Research results of Kalefetoğlu (2006) and Ceyhan et al. (2012b) showed that content of CAT increased depending on drought.

Proline content: Means of the genotypes showed that proline contents (Table 1) of the stress groups ranged from 1.68 (control) to $15.26 \mu \mathrm{g} / \mathrm{FW}$ (7 days). The highest proline content occurred in the genotypes $22117(12.59 \mu \mathrm{g} / \mathrm{FW})$ and Canitez $(12.27 \mu \mathrm{g} / \mathrm{FW})$. The lowest proline content was $8.30 \mu \mathrm{g} / \mathrm{FW}$ in Beysehir LP genotype (Table 2).

Proline was found to be occumulated in a large scale under drought stress (Kalefetoğlu 2006, Tan et al. 2006, Ceyhan et al. 2012b). The present result also showed increasing of proline content in chickpea genotypes under drought stress. Kalefetoğlu (2006) suggested that proline controls turgor and protects cell water. Similarly, Tan et al. (2006) detected an increasing proline content depended on the level of water scarcity and time.

Table 3. Means squares of investigated characteristics in chickpea genotypes under different levels of drought.

\begin{tabular}{|c|c|c|c|c|c|c|}
\hline Variation sources & LWAC & RWC & REWC & $\begin{array}{c}\text { Chlorophyll } \\
\mathrm{a}\end{array}$ & $\begin{array}{c}\text { Chlorophyll } \\
\text { b }\end{array}$ & $\begin{array}{c}\text { Chlorophyll } \\
\mathrm{a}+\mathrm{b}\end{array}$ \\
\hline Genotypes (G) & $* *$ & $* *$ & $* *$ & $* *$ & $* *$ & $* *$ \\
\hline Stress groups (SG) & $* *$ & ns & $* *$ & $* *$ & $* *$ & $* *$ \\
\hline $\mathrm{G} \times \mathrm{SG}$ İnt. & $* *$ & $* *$ & $*$ & $* *$ & $* *$ & $* *$ \\
\hline Variation sources & POD & SOD & Proline & GR & AP & CAT \\
\hline Genotypes (G) & $* *$ & ns & $* *$ & $* *$ & $* *$ & $* *$ \\
\hline Stress groups (SG) & $* *$ & $* *$ & $* *$ & $* *$ & $* *$ & $* *$ \\
\hline $\mathrm{G} \times \mathrm{SG}$ İnt. & $* *$ & ns & $* *$ & $* *$ & $* *$ & $* *$ \\
\hline
\end{tabular}

$*: \mathrm{p}<0.05 ; * *: \mathrm{p}<0.01 ; \mathrm{ns}$ : non significant.

In conclusion, statistical analysis for LWAC, RWC, REWC, chlorophyll $\mathrm{a}, \mathrm{b},(\mathrm{a}+\mathrm{b}), \mathrm{POD}$, SOD, GR, APX, CAT and proline content in genotypes, stress and genotypes $\times$ stress were significant (Table 3). The most drought resistant genotypes were Cumra LP, Canitez, Kusmen-99, 22117 and 22223 may be due to enzyme activity in the leaves. It is clear that drought stress changed the activity of antioxidant enzymes and proline content in all the used genotypes significantly and response of genotypes varied in a large scale. Future researcher supposed to analyze of all the drought stress tolerant chickpea genotypes throughout the widely used lines and breeding programs should be supported as well as using of the promising genotypes.

\section{Acknowledgment}

The authors are thankful for the support extended by TUBITAK (Project number: 108 O 742) and Selcuk University Scientific Research Projects (BAP). This paper is a part of this project and was summarized from M.Sc. thesis of the first author (EG). 


\section{References}

Anyia AO and Herzog H 2004. Genotypic variability in drought performance and recovery in cowpea under controlled environment. J. Agro. Crop Sci. 190: 151-159.

Arora A, Sairam RK and Srivastava GC2002. Oxidative stress and antioxidative systems in plants. Cur. Sci. 82: $1227-1238$.

Bates LS, Waldren RP and Teare ID 1973. Rapid determination of free proline for water-stress studies. Plant Soil 39: 205-207.

Bergmeyer HU 1970. Methods of Enzymatic Analysis. Verlag Chemie, Weinheim/Bergstr, German.

Beauchamp C and FridovichI 1971. Superoxide Dismutase: improved assays and applicable to acryl amide gels. Analytical Biochemistry 44: 276-287.

Ceyhan E, Önder M, Kahraman A, Topak R, Ates MK, Karadas S and Avci MA 2012 a. Effects of drought on yield and some yield components of chickpea. World Academy of Science, Engineering and Technology 66: 378-382.

Ceyhan E, Kahraman A, Önder M, Ates MK, Karadas S, Topak R and Avci MA 2012b. Physiological and biochemical responses to drought stress of chickpea genotypes. World Academy of Science, Engineering and Technology 66: 383-388.

Ceyhan E, Önder M, Harmankaya M, Hamurcu M and Gezgin S 2007. Response of chickpea cultivars to application of boron in boron deficient calcareous soils. Communications in Soil Science and Plant Analysis 38: 2381-2391.

Clarke JM and McGaig TN 1982. excised-leaf water retention capability as an indicator of drought. J. Plant Sci. 62: 571-578.

Costa Franca MG, Pham-Thi CAT, Pimentel ROP, Rossiello Y, Fodil Z and Laffray D 2000. Differences in growth and water relations among Phaseolus vulgariscultivars in response to induced drought stress. Environ. Exp. Bot. 43: 227-237.

Farrant JM 2000. A comparison of mechanisms of desiccation tolerance among three angiosperm resurrection plant species. Plant Ecol. 151: 29-39.

Foyer CH and Halliwell B 1976. The presence of glutathione, glutathione reductase in chloroplasts: a proposed role in ascorbic metabolism. Planta 133: 21-25.

Fu J and Huang B 2001. İnvolvement of antioxidants and lipid peroxidation in the adaptation of two coolseason grasses to localized drought stress. Environ. Exp. Bot. 45: 105-114.

Jiang HF and Ren XP 2004. The effect on SOD activity and protein content in groundnut leaves by drought stress. Acta Agromomica Sinca 30: 169-174.

Kalefetoğlu T 2006. Characterization of chickpea (Cicer arietinumL.) cultivars and lines tolerance to drought stress. Master Thesis, Haccetepe Universiy, Ankara, Turkey.

Keles Y and ÖnceI 2002. Response of antioxidative defence system to temperature and water stress combinations in wheat seedlings. Plant Sci. 163(4): 783-790.

Kumar KB and Khan PA1982. Peroxidase and polyphenol oxidase in excised ragi (Eleusine coracana cv. PR 202) leaves during senescence. Ind. J. Expt. Bot. 20: 412-416.

Lichtenthaler HK 1987. Chlorophylls and carotenoids: pigments of photosynthetic biomembranes. Method Enzymol. 148: 350-382.

Mani S, Van De CotteB, Van MontaguMand VerbruggenN 2002. Altered levels of proline dehydrogenase cause hypersensitivity to proline and its analogs in Arabidopsis. Plant Physio. 128: 73-83.

Moran JF, Becana M, Iturbe-Ormaetxe I, Frechilla S, Klucas RV and Aparicio-Tejo P 1994. Drought induces oxidative stress in pea plants. Planta 194: 346-352.

Nakano Y and Asada K 1981. Hydrogen peroxide is scavenged by ascorbate-specific peroxidase in spinach chloroplasts. Plant Cell Physio. 22(5): 867-880.

Shao L, Young LT and Wang JF 2005. Chronic treatment with mood stabilizers lithium and valproate prevents excitotoxicity by inhibiting oxidative stress in rat cerebral cortical cells. Biol. Psychiatry 58: 879-884. 
Singh KB 1997. Chickpea (Cicer arietinum L.). Field Crops Res. 53: 161-170.

Tan Y, Liang Z, Shao H and Du F 2006. Effect of water deficits on the activity of anti-oxidative enzymes and osmoregulation among three different genotypes of Radix astragaliat seeding stage. Colloid Surface B 49: 59-64.

Turkan I, Bor M, Ozdemir F and Koca H 2005. Differential responses of lipid peroxidation and antioxidants in the leaves of drought-tolerant $P$. acutifoliusGray and drought-sensitive $P$. vulgaris L. subjected to polyethylene glycol mediated water stress. Plant Sci. 168: 223-231.

(Manuscript received on 7 April, 2014; revised on 7 April, 2015) 